\title{
Bir Piyasa Düzenleme Mekanizması Olarak Bursa İhtisab Kanunnamesi
}

\author{
The Bursa Specialization Law as a Market Regulatory Mechanism
}

\section{Türkan POLATCI DEMIRKOL*}

Öz: II. Bayezid döneminde Osmanlı Devleti pek çok açıdan gelişim göstermiştir. Bu dönemde Osmanlı şehirleri arasında özellikle Bursa hem ticari bir merkez olması, hem de batı ile doğu arasında iktisadi anlamda bir köprü görevi görmesi bakımından önemli şehirlerden bir tanesidir. Osmanlı Devleti'nin gelişmesine paralel olarak sosyo-ekonomik ve kültürel alanda ilerleme kaydeden şehir, Anadolu'da önemli ticaret merkezlerinden biri haline gelmiştir. Bu gelişmenin bir sonucu olarak da ticaretin sağlıklı yapılabilmesi için devletin denetim mekanizmalarını yerinde kullanarak piyasayı düzgün ve sürekli kontrol altında tutması gerekmektedir. Bu anlamda devletin en önemli denetim araçlarından birisi narh sistemidir. Uygulanan narh sistemi ile de sadece mal ve hizmetlerin satış fiyatlarının belirlenmesi değil, aynı zamanda alınan, satılan ve işlenen her türlü emtianın; üretim şartlarının ve standardının belirlenmesi yoluna gidilmiştir. $\mathrm{Bu}$ yöntem tüketicinin haklarını koruyan önemli bir düzenlemedir. Narh sistemi ve ihtisab uygulamaları hakkında günümüze kadar ulaşan en eski belgelerden birisi 1502 tarihli Bursa İhtisab Kanunnamesidir. Bu çalışma, söz konusu kanunname üzerine genel bir değerlendirme ortaya koymanın yanında aynı zamanda da Bursa'da esnafin durumunu ve devletin ekonomik denetim mekanizmalarını işletme şekillerinin anlaşılması açısından önemlidir.

Anahtar sözcükler: II. Bayezid, Bursa, İhtisab Kanunnamesi, Narh

\begin{abstract}
During the reign of Bayezid the Second, the Ottoman state achieved development in many aspects. Amongst Ottoman cities of this period, Bursa was one of the important cities, being a commercial centre as well as serving as an economic bridge between the east and the west. In parallel with the development of the Ottoman State, the city making progress in socio-economic and cultural areas became one of the important trade centres in Anatolia. As a result of this development, it was necessary for the state to use the supervision mechanisms in place and keep the market properly and constantly controlled, this so that healthy trade could be achieved. In this sense, one of the most important control instruments of the state was the ceiling system. With the implementation of the ceiling system, not only the sales prices of goods and services were determined, but also the production conditions and the standards of all types of commodities that were received, sold and/or processed in each area were determined. This was an important regulation that protected the rights of the consumer. The Bursa Specialization Law dating from 1502 is one of the earliest documents concerning the ceiling system and specialization regulations. In addition to an overall assessment of the law, this study notes the importance of understanding the situation of tradesmen in Bursa and the operational modes of the Ottoman state's economic control mechanisms.
\end{abstract}

Keywords: II. Bayezid, Bursa, Specialization Law, Ceiling

\footnotetext{
*Yrd. Doç. Dr., Çankırı Karatekin Üniversitesi, Edebiyat Fakültesi, Tarih Bölümü, Çankırı. tpolatci@ karatekin.edu.tr
} 


\section{Giriş}

15. yüzyılın ortalarından 17. yüzyılın sonlarına kadar geçen bir buçuk asırlık dönem, Osmanlı Devleti'nin siyasî, askerî, iktisadî, sosyal ve kültürel alanlarda büyük gelişme göstererek dünya genelinde hâkimiyet kurduğu bir dönem olmuştur. Siyasi kudret açısından tarihindeki en yüksek seviyeye ulaşan devlet, bu üstünlüğünü dil, edebiyat, kültür ve sanat alanlarında da göstermiştir. $\mathrm{Bu}$ yüzyıllarda Osmanlı, dünyanın cazibe merkezi olurken aynı zamanda da dünya siyasi hayatında söz sahibi olan büyük bir güç haline gelmiştir. Bu durum halkın kültür ve refah seviyesini de doğrudan etkilemiştir.

Osmanl1 16. yüzyıla, devletçi bir politika izleyen babası Fatih'in aksine yönetimde daha uzlaştırıcı bir tutum benimseyen II. Bayezid'in 1lımlı yönetimi ile girmiştir. Bu 1lımlı siyaset bir taraftan ülkenin sosyo-iktisadi yapısını olumlu yönde etkilerken diğer taraftan da özellikle göçebe topluluklar gibi Osmanlı hâkimiyetinden memnun olmayan grupları da isyana karşı cesaretlendirmiştir. Bu durumun ortaya çıkmasında şüphesiz ki II. Bayezid'in kardeşi Cem'in saltanat mücadelesinin uluslararası bir soruna dönüşmesinin de büyük etkisi vardır. Kaldı ki yaşanan bu rekabet Avrupalı Devletler açısından bakıldığında İstanbul'u geri alma umudunu doğurmuştur. Bu nedenle II. Bayezid saltanatı süresince her zaman daha dikkatli ve barışçı bir yönetim gerçekleştirmeyi amaçlamıştır (Turan 1992, 235). Bu sayede ülke içinde hatırı sayılır bir gelişme yaşanmış ve birçok Osmanlı şehri de ekonomik manada canlılığa kavuşarak bir kent kimliğine bürünmüştür (İnalcık 2000, 54-55). Özellikle tımar sistemi, toprak tasarrufu ve vakıflar alanlarında birtakım düzenlemelerin yapıldığı, devlet kurumlarının sağlam temellere oturtulduğu II. Bayezid döneminde başarılı bir örgütlenme ve yönetim gerçekleştirilmiş̧ir.

$\mathrm{Bu}$ çalışmanın amacı; bugünkü manada dünyanın ilk standardı olarak kabul edilen Bursa İhtisab Kanunnamesi'nin genel bir değerlendirmesinin yapılmasıdır. $\mathrm{Bu}$ amaç doğrultusunda mevcut piyasa şartlarında meydana gelen bozulmanın düzeltilmesi amacıyla hazırlanan kanunnamede narh sisteminin bozulma sebepleri ve narhın belirlenmesinde dikkate alınan hususların neler olduğuna dair sorulara cevap aranmıştır.1502 tarihli kanunname 1998 yılında Türk Standartları Enstitüsü tarafından latinize edilerek yayınlanmış ancak metne ilişkin sadece iki adet akademik çalışma yapılmıştır. Bu çalışmalar da metnin içerisinde yer alan iş kollarından yalnızca ikisine değinilerek hazırlanmış, metnin tamamına dair herhangi bir çalışma yapılmamıştır.

\section{Osmanlı Devletinde Fiyat Politikasının Esasları}

Osmanlı Devleti, himayesinde bulunan toplulukları aralarında hiçbir ayrım gözetmeksizin yüzyıllarca idare etmiştir. Osmanlı resmi terminolojisinde "reâyâ" olarak isimlendirilen müslim ve gayrimüslim halkları koruma ve adaletli bir şekilde yönetme şüphesiz ki, otorite sahibi olan padişaha ait bir görev sayılmıştır. Osmanlı klasik çağında söz konusu terim daha ziyade vergi veren halkı kapsamakla birlikte Tanzimat öncesi dönemde ise "gayrimüslim Osmanlı tebaası" n1 karş1lar bir niteliğe bürünmüştür (Öz 2007, 490-493). Çeşitli dönemlerdeki bu farkl1lıklara rağmen vergi vermekle mükellef halkı kapsayan bu terim bize esas itibariyle Osmanlı fiyat politikalarının temeli hakkında da ipucu vermektedir.

Osmanlı yönetim yapısında söz konusu vergi mükellefiyeti bulunan reâyânın vergisine konu olan gelirinin, üretici-tüketici ilişkileri ve tüketicinin korunması bağlamında tedbirler alınarak denetlenmesi için devletin sıkı bir denetim mekanizması kurması gerekmektedir. Daha ziyade şer'i hukuk bağlamında İslami gelenekle temellendirilen (Osmanlı şehir hayatında ihtisab işlerinin düzene sokulması şeriatın temel kuralı olan "emr bi'l-ma 'ruf nehy ani'l münker" hükmüne dayanmakla birlikte Kur'an da bu kuralın geçtiği ayetler için Bk. Kur'an, Al-i Imran, 3/104; Tevbe 9/71, 112; Hud 11/116) bu denetim mekanizması Osmanlı ekonomisi açısından 
bakıldığında hükümdara da toplumsal yaşayışı düzenleme hususunda önemli yetkiler vermektedir (Tabakoğlu 1989, 620-625).

Osmanlı fiyat politikalarının sağlıklı olarak yürütülebilmesi için gerekli kurumsal çerçeveyi esnaf teşkilatı oluşturmakla birlikte piyasanın denetlenmesi görevi de daha ziyade kadı ve muhtesibler tarafindan gerçekleştirilmektedir. Osmanlı ekonomisinin prensip olarak benimsediği ilkelerden bir tanesi de şüphesiz ki, ticaret serbestisinin geliştirilmesidir. Bu nedenle ticari eylemlerde tekelci faaliyetlerin artmasının önüne geçilerek üretici ve tüketicinin zarara uğramasına engel olunmaya çalışılmıştır (Tabakoğlu 1989, 629-633; 2005, 162). Bu sebeple de fiyatlara "narh" konulmuştur. Narh uygulaması esas itibariyle mal ve hizmet fiyatlarında devletçe tespit edilen üst sinırı ifade eder. Ancak piyasa şartları göz önünde bulundurularak uygulanan bu sistemde fiyat tespitini arz-talep durumu belirler (Kütükoğlu 2006, 390-391). Bu uygulama aynı zamanda piyasa fiyatlarının seyrinin takibini de gerektirmekle birlikte, bu görev muhtesiblere aittir.

Osmanlı Devleti'nde daha ziyade "ihtisab ăgası" veya "ihtisab emini" olarak isimlendirilen muhtesib; devletin kuruluşuyla birlikte ortaya çıkmış, devletin gelişimine paralel olarak da görev ve yetkileri zamanla daha net olarak şekillenmiştir. Daha ziyade iktisadi konularda kadının yardımcısı olarak vazifelendirilen muhtesibler bazen de sadrazamla birlikte şehirde dolaşarak narh ile ilgilenir ve esnafın kanunlara uyup uymadığını denetleyerek ekonomik ve sosyal hayatın önemli bir parçasını oluştururlardı (Kazıcı 1985, 332-333; 1998, 143-144). Dolayısıyla bu görevi üstlenecek kişilerin özellikleri ve seçimleri de oldukça önemliydi.

Osmanlı şehir hayatının özellikle beledî mevzuatının uygulayıcısı olan muhtesibler otorite ve yetkilerini kadılardan alarak çarşı ve pazarın düzenini sağlarlardı (Erdoğdu 2001, 134-135). Buradan hareketle özellikle İhtisab Kanunnameleri'nde önemle üzerinde durulan konulardan birisinin fiyat denetimi ve hammadde kalitesi olduğu söylenebilir (Yıldız 2010, 1471-1472; Bk. Kanunname-i İhtisab-ı Bursa (KİB) 1998). Muhtesiblerin görevlerini yerine getirmeleri için başvurdukları en önemli yasal dayanakları, II. Bayezid döneminden itibaren hazırlanan bu kanunnamelerdir (Öneş 1985, 34-35). Çalışmada özellikle üzerinde durulacak olan Bursa İhtisab Kanunnamesi de bu manada kalite, boyut, ambalaj gibi konularda standartlar tespit etmiş, narh ve ceza hükümlerine de yer vermiştir. Dolayısıyla da bugünkü standardizasyon sistemine benzeyen bir sistem tesis edilmiştir.

\section{Osmanlı Döneminde Bursa'nın Sosyo-Ekonomik Yapısı}

1326 yılında Osmanlı egemenliğine giren Bursa, devletin kuruluş ve gelişme safhalarında Anadolu'dan geçen ipek ve baharat yollarının üzerinde bulunması dolayısıyla oldukça önemli bir konuma sahiptir. Kaldı ki, 1326-1361 yılları arasında Osmanlı'ya başkentlik yapması, verimli toprakları ve İstanbul'a yakınlığı ile her dönemde ön planda olarak bu önemini daha da arttırmıştır (Akkuş 2009, 1-3). I. Murad'ın 1365 tarihinde Edirne'yi başkent yapmasından sonra da Bursa şehri, tahta çıkışlar, cenaze törenleri ve diğer önemli törenlerle sembolik başkent olma özelliğini korumuştur.

Ekonomik anlamda Bursa'nın uluslararas1 pazar konumuna yükselmesi ise 14. yüzyılın ortalarından itibaren başlamıştır (İnalcık 2000, 274). Osmanlı Devleti'nde özellikle ipek imalât ve ticaretinin (bilhassa İran ipeğinin Avrupa'ya aktarılması hususunda) (İnalcık 2000, 277-300) merkezi olan kent, coğrafi konumunun da getirdiği avantajla sadece politik bir merkez olmakla kalmamış aynı zamanda devletin gelişmesine paralel olarak sosyo-ekonomik ve kültürel anlamda da gelişme göstermiştir.

Bursa'nın Osmanlı egemenliğine geçmesinden sonra buraya ilk gelen seyyah İbn-i Battuta 
olmuştur. 1333 yılında şehre gelen seyyah, buranın muazzamlığından, çarşılarının canlılığından bahsederek Bursa'yı büyük caddeleri bulunan bir belde olarak tarif etmiştir (İbn Battûta 2000, 428-430). Timur'un Anadolu'yu istilası ve akabinde yaşanan fetret döneminde Bursa'nın gelişmesine darbe vurulmuş olsa da zamanla şehir eski ticari canlılığına tekrar kavuşmuştur. Özellikle Fatih Sultan Mehmed döneminde Bursa her daim İstanbul'a rakip bir şehir olarak gelişme göstermiştir. Böylelikle başkentin hem rakibi hem de tamamlayıcısı olmuştur. Özellikle doğuya karşı girişilen seferlerde askeri bir üs olarak kullanılmakla kalmamış (İnalcık 1992, 447) aynı zamanda da uluslararası bir ticaret merkezi haline dönüşmüştür. Bu ticaret yalnızca DoğuBatı ekseninde sınırlı kalmamış, şehri Anadolu ve Rumeli ticaretinin de kısa sürede merkezi konumuna getirmiştir (İnalcık 1960, 45-46).

Genel kaide üzere bir şehri değerlendirirken üzerinde durulması gereken en önemli hususlardan bir tanesi de onu çevreleyen bölge ve diğer yerlerle etkileşimini ortaya koymaktır. Osmanlı şehirleşme siyasetinin merkezinde bulunan esas önemli konu ise devletin izlediği nüfus dağılımını düzenleme politikasıdır. Bu anlamda bakıldığında özellikle İstanbul'a ulaşan yol üzerinde bulunan karayolu taşımacılığının en önemli güzergâhlarından bir tanesi Bursa'dır (Faroqhi 2006, 43-47). Bursa, ticari ve politik anlamda önemli bir noktada bulunması dolay1sıyla da Osmanlı Devleti'nin ikinci büyük şehridir. Bu yönü ile de hem doğulu hem de batılı tacirlerin yoğun olarak yerleştiği bir şehir olmuştur (İnalckk 1960, 46).

Bursa, özellikle İtalyan tacirleri açısından doğudan gelen malların bir antreposu durumunda bulunmaktadır ki pazarında her çeşit ipekli kumaş, bol miktarda inci, pamuklu ve kadife kumaşların yanında çok çeşitli ticari eşyanın ticareti yapılmaktadır. Bundan başka Hintli, Halep ve Şamlı tacirler de Bursa' da yoğun ticari faaliyetlerde bulunmaktadırlar (İnalcık 1960, 47-50). 14. yüzyıldan başlayarak özellikle ipek ticareti ve endüstrisinin uluslararası merkezi konumunda olan Bursa (Schiltberger 1997, 89) bu durumunu 17. yüzy1la kadar sürdürmüştür. Özellikle II. Bayezid devrinde devletin Doğuya karşı izlediği 1lımlı politika Bursa açısından ipek ithalatını rekor seviyeye ulaştırmıştır (İnalcık 2000, 281).

Bursa'da ekonomik refahın kaynağı olarak görülen ipek ticaretinin gelişmesinin en önemli nedenlerinden bir tanesi de şüphesiz ki İran'dan gelen ipeğin Osmanlı sınırlarındaki ikinci gümrük yerinin Bursa olmasıdır (İran ipeğinin ilk gümrük yeri Tokat ikincisi ise Bursa'dır Bk. İnalcık 1960, 52). İpekli malların Bursa'dan başka yere gitmemesi için devlet tarafindan sık1 tedbirler de alınmıştır (Anhegger \& İnalcık 1956, 40-41). Daha ziyade mahalli dokuma tezgâhlarında tüketilen ipek, şehirde özel teşebbüsçe desteklenen dokuma tezgâhlarının sayısını da arttırmıştır. Bu tezgâhlarda çalışan ipek işçilerinin çoğu köle statüsünde bulunmakla birlikte bunlar belirli bir süre sonra azat edilerek zamanla müteşebbis konumuna getirilmişlerdir (İnalcık 1992, 448). Hatta kadın müteşebbislerin de şehirde bu alanda uğraş verdikleri bilinmektedir (Maydaer 2006, 375-379).

Bursa ekonomik olarak sadece İran ipeğinin bir pazarı olarak kalmamış aynı zamanda Avrupa yünlü üretiminin de doğuya naklinde de önemli bir merkez konumuna gelmiştir (İnalcık 1960, 55-56). Hatta sarayın kumaş, altın para vs. ihtiyaçları ile iç pazarın kumaş ihtiyacı da Bursa'dan karşılanmakla birlikte özellikle kadife ve kemhaları en değerli kumaşlar arasında yer almakta; Padişah'ın akrabaları, elçiler ve devletin ileri gelenlerine verilen hediyeler arasında özellikle bulundurulmaktaydı (İnalcık 1960, 63-64). Bu yoğun ekonomik yaşamı dolayısıyla Bursa, aynı zamanda bir kültür şehri konumuna gelmiş, yaşanan iktisadi faaliyetlere paralel olarak şehirde birçok imar faaliyeti de gerçekleştirilmiştir (İnalc1k 1992, 448-449).

Ancak zamanla devletin gerileme sürecine girmesi ile Bursa'da da bir duraklama ve gerileme süreci yaşanmış, ard arda yapılan savaşlar, devleti derinden etkileyen isyanlar, kıtlık ve doğal 
afetler dolayısıyla Bursa ve çevresindeki ekonomik yapı da olumsuz yönde etkilenmiştir.

\section{Ekonomik Denetim Mekanizması Olarak II. Bayezid Dönemi’nde Bursa'da İhtisab Uygulamaları}

II. Bayezid döneminde Bursa'da hayata geçirilen ve günümüze kadar ulaşan ekonomik denetim mekanizmasını yansıtan en önemli belge şüphesiz ki Bursa İhtisab Kanunu'dur. 1502 tarihinde Mevlana Yaraluca Muhyiddin (Mehmed Süreyya 1996, 1105; Ahmed Bâdî Efendi 2014, 1169) tarafından hazırlandığı bazı kaynaklarda (Akgündüz \& Öztürk 1999, 126; Karataş 2012, 48) ifade edilmiş olmasına rağmen bu durum aslında pek mümkün görünmemektedir. Şöyle ki söz konusu kişi kanunun hazırlanmasından yaklaşık olarak 8 yıl önce vefat etmiş, hatta ilk olarak müderrislik, ardından Edirne Kadılığı görevine getirilmiş, "sîret-i hasene" yani iyi ahlak üzere hareket etmediği için azlolunarak Sultan Bayezid'e hoca tayin edilmiş yine mizacı dolayısıyla bu görevden de azlolunup tekrar Edirne Kadısı olmuş ve yeniden azledilmiştir. Dolayısıyla mizacından dolayı sürekli azledilen ve kanunun hazırlanmasından önce vefat eden bir devlet görevlisinin bu kanunu hazırlaması ihtimali oldukça düşüktür.

Bursa İhtisab Kanunnamesi, en genel ifade ile şehirde üretimi gerçekleştirilen ve ticari faaliyete konu olan ürünlerin hem kalitesini denetleyen hem de satış fiyatlarını düzenleyen hukuki bir metin özelliği taşımaktadır. Bu noktada üzerinde durulması gereken husus ticari faaliyete ilişkin bir uygulamanın söz konusu olmasıdır. Şehirde gerçekleşen ticari faaliyetin denetimi ve düzenlenmesi, bunun yanı sıra esnafın çıkarlarının da gözetilerek dolayısıyla da devletin vergi noktasında kendi çıkarlarını koruması anlamına gelmektedir. Söz konusu kanunnameden yola çıkarak Bursa'da ticari üretim yapan iş kolları şu şekilde sınıflandırılabilir (Bk. KİB 1998):

Tablo 1. Bursa'da Ticari Üretim Yapan İş Kolları

\begin{tabular}{|l|l|l|}
\hline Ekmekçiler & Kasaplar & Pazarcılar \\
\hline Bostanlar (Çiftçi) & Helvacılar & Bakkallar \\
\hline Balıçılar & Aşçılar & Yumurta ve Tavuk Üreticileri \\
\hline Börekçiler & Sakatatçlar/ Çorbacılar & Dokumacılar \\
\hline Terziler & Kürkçüler & Kökelciler (Bezciler) \\
\hline Kunduracılar & Mutaplar (Çuvalcılar) & Nalbantlar \\
\hline Keresteciler & Kuyumcular & Bakırcılar \\
\hline Takkeciler & Hallaçlar & Attarlar \\
\hline Sütçü ve Yoğurtçular & Çilingirler & Kerpiççiler \\
\hline Mezar Kazıcıları & Pirinççiler & Debbağlar \\
\hline
\end{tabular}

Kanunnameye konu olan iş kollarının denetiminde ilk referans noktasını o dönemde uygulamada olması gereken kanun oluşturmaktadır. Denetimin ilk ayağını var olan kanunun (narhların) uygulanıp uygulanmadığının tespiti oluşturmaktadır. Bu hususta öncelikle üretici ve denetimi yapılacak iş kolunun bilirkişilerine işkolunun mevcut narhının olup olmadığı, var ise uygulanıp uygulanmadığ 1 ve uygulanmıyor ise nedeni sorulur. Hatta bazen bu sürece şehrin ileri gelenleri ve halkın arasından seçilenler de dâhil edilirdi. Kanunun uygulanmadığının tespit edildiği durumlarda ise şehrin yöneticilerinden uygulamada olan kanunun bozulma sebeplerinin açıklanması istenirdi. Tüm sorgulamalar neticesinde üretilen ürüne ilişkin yeni narh belirlenerek deftere kaydedilirdi.

16. yüzyılın başında Bursa'da yaşanan narh sistemindeki bozulmanın en önemli sebeplerinden birisi şehirde denetleme işini icra eden kamu görevlilerinin ihmalleridir. Bu ihmalleri iki başlık altında ele almak mümkündür. Bunlardan birincisi kamu görevlilerinin yetkilerini suiistimal etmesidir. Başka bir ifade ile denetim mekanizmasında yolsuzluk ve rüşvetin baş göstermesidir: 
“...Haftada bir gün Belediye Reisinin adamı şehirlilerden bazı dürüst kimselerle kabbâna gelip baldan, yağdan ve gayrısından ne varsa onu onbir üzerine narh verip sicillere kaydettirir ve narha aykır bir hareket bulununca günahına göre hakkından gelinirdi. Dört beş ylldır görülüyor ki bu kanuna riayet olunmayıp her bakkal dilediği veçhile alıp satar nedeni yukarıda açıklandı̆̆ı gibi akça alıp susmaktır" (KİB 1998, 13).

Denetim mekanizmasında baş gösteren rüşvetin ve yolsuzluğun boyutları oldukça vahimdir. Kanunnamede yer alan iş kolları arasında kamu görevlilerinin aldığı rüşvet yüzünden bozulmamış iş kolu neredeyse bulunmamaktadır. Söz konusu rüşvet durumuna yalnızca hallaçlar ve çilingirlerde rastlanmamaktadır. Ancak buradaki durumun altında yatan esas unsur bu iki iş koluna ait herhangi bir narhın daha önceden de belirlenmemiş olmasıdır.

Kamu görevlilerinin görev ihmalleri ile ilgili ikinci husus ise bu ihmal karşısında esnafın suistimalidir. Kamu görevlilerinin denetim işlevlerini tam anlamıyla yerine getirmemesi karşsında bazı esnaf özellikle tartım aletlerinde hileye başvurmaktadır:

“...tartı ve ölçeklerin her birinde ikiyüz kırkyedi dirhem eksik bulunmuş, bir mud, bir kile ve seksensekiz kile dirhem eksik tesbit edilmiş. Üzerlerinde belediye başkanının mührü ve damgası mevcut. Bunca zamandan beri noksanlarına bakmazlarmış..." (KIBB 1998, 26).

Narh sisteminin bozulma sebeplerinden ikincisi ise karaborsacılıktır. Karaborsanın ortaya çıkmasında en önemli etken üretilen malın piyasaya arzı öncesinde el değiştirmesidir:

"...eskiden Pazar yerine her ne çeşit meyve gelirse şehirli ve pazarcl herkes istediğine göre alırdl. Dört beş yll var ki pazarcılar birleşip şehre gelen meyveleri ve şehir etrafinda olan bă̆ ve bahçe ve bostanlart yerlerinde toptan satın alıp meyvelerini dükkânlarına getiriyor, depo ediyor ve Belediye başkaninın da ittifaklyla her birine narh koydurulup mahkeme sicillerine geçiriliyor. Fakat dışarıda bildiklerine satarak Belediye Başkant ile paylaşıyorlar...” (KİB 1998, 7).

Karaborsanın oluşmasında üreticilerin veya toptancıların ürünleri depolamalarının yanı sıra denetim mekanizmasının işlerliğini sağlamakla vazifeli kamu görevlilerinin aldıkları rüşvet de etkili bir unsurdur. Bir anlamda karaborsayı yaratanlar kamu görevlilerini de arkalarına alarak oluşturdukları sistemi meşru hale getirmektedirler. Üretilen ürünlerin tüketiciye ulaşması noktasında karaborsanın oluşmasının yanı sıra üreticilerin arasında da karaborsanın oluştuğu görülmektedir. Şöyle ki:

“... Ve şikâyetle bundan önce dişarıdan ne kadar iplik gelirse esnafimız pazara varıp getirenlerden fiyatı ile alırlardı. SSimdiki halde iplik pazarında olan dükkân sahipleri ipliği biz varmadan alırlar. Biz varıp bulamayız. Naçar kalıp dükkâncılardan onu on iki üzerine ve belki daha fazla üste verip alırız" (KİB 1998, 21).

Bez, çul ve peştamal üreticilerinin şikâyetçi olduğu bu durumun temel sebebi dokumacı esnafinın hammadde temini noktasında oluşturduğu tekeldir. $\mathrm{Bu}$ tekel sayesinde hammadde fiyatlarındaki yükselme, üretim maliyetlerini doğrudan etkileyerek malın satış fiyatını yükseltmekte ve devletin belirlemiş olduğu narh sistemi de sekteye uğratmaktadır.

Narh sistemi her ne kadar piyasa fiyatları üzerinde devletin denetim mekanizmasını işletme yöntemi olsa da aynı zamanda üreticinin üretim şekillerini ve standartlarını da belirleyen bir 
unsurdur. Bursa İhtisab Kanunnamesi’nde narh sisteminin bozulmasına ilişkin üçüncü unsur da üreticinin devletin belirlediği üretim şekli ve standartlarına uymaması, başka bir ifade ile meslek ahlakında meydana gelen bozulmadır. Belirlenmiş üretim şekil ve standartlarına uymama durumu çoğunlukla "hileli mal" şeklinde ortaya çıkmaktadır:

“Çifte taftanın çözgüsü binsekizyüz çifte tel olup eni de beş rub’u girahda olurdu. Taftanin yüzüne pürüzü yatsin diye el ayası ile zamk sürülürdü. Bu tarihten beri bunun da çözgüsünden kimi ikiyüz ve kimi üçyüz ve dörtyüz tel çıkartp tel noksanliğından ötürü seyrelince ister istemez sağlam görünsün diye zamk suyuna tuz katup sürerler"(KİB 1998, 18).

Dokumacıların "sağlam görünsün diye" başvurdukları hileli mal için yaptıkları savunma ise hammaddenin hileli ya da eksik malzeme ile üretilmiş olmasıdır. Dokumacılar kusurlu hammaddeden haberdar olsalar da üretim standartlarında değişiklik ya da fiyatta değişiklik gibi bir yola başvurmak yerine hileli mal üretme yolunu tercih etmişlerdir. Kuyumcularda da benzer bir durum görülmektedir:

“...Padişahlik yüksek makamından hüküm gelip metninde gümüş cinsinden her ne işlenirse seksen ayar olsun, bundan eksik işlenmesin diye emr olunmuştur. Dediklerinde gerçekte bu şekilde hüküm olduğu ve yapılan işler incelendiğinde gümüş lehimli bakır düğmeler bulundu" (KİB 1998, 24).

Padişahlık emri olmasına karşın kuyumcuların "hileli mal" üretmeleri, dokumacıların durumları ile kıyaslandığında daha da vahimdir. Çünkü burada söz konusu olan hammaddenin eksikliği ya da hileli üretimi kuyumcular için söz konusu değildir. Kendileri ise bu durumu şöyle açıklamaktadırlar:

“...Biz işlemiyoruz. İstanbul kuyumcuları işliyor. Yolcu alıp buraya getiriyor, biz onlardan alyyoruz dediler" (KİB 1998, 24).

Hileli malın üretimi noktasında sorumluluğu İstanbul kuyumcularına atarak Bursalı kuyumcular kendilerini temize çıkarmaya çalı̧̧maktadırlar. Burada iki önemli sonuç ortaya çıkmaktadır. Ya gerçekten İstanbul kuyumcuları hileli mal üretmekte ve İstanbul narh sistemi de bozulma emareleri göstermektedir. Ya da her iki şehrin kuyumcu esnafi arasında hileli mal üretimi ve satış1 noktasında bir anlaşma bulunmaktadır. Her ne kadar Bursa kuyumcuları hileli malı üretmemiş olsalar da satışını yaptıkları gerçeği gözden kaçırılmamalıdır.

Sistemin bozulmasında tespit edilen bir diğer sebep ise üretim için gerekli hammaddenin tedarikinde yaşanan sıkıntılardır. Bu sıkıntıların sonucunda üretim için belirlenmiş şartlar oluşmadığından tespit edilen narhlarda bozulma meydana gelmektedir:

“... Üç dört yıl var ki gelen boğasılar asla tamam gelmez. Tümü eksiktir. Bu yüzden kaftan kisa olup tamam olmaz. Eski adet üzere biçmeğe yetmez dediler" (KİB 1998, 20).

Üretim için yeterli hammaddenin olmaması hileli mal üretimi için bir gerekçe gibi görünse de buradaki temel sıkıntı piyasada var olan arz-talep ilişkisinde yaşanan değişimdir. Hammaddenin eksik olmasının yanı sıra üretilen ürünlerin alıcı profilindeki değişim, talebi karşılayamamaktadır:

“...Bundan böyle tamam olsun denildi. Amma kürkçüler şikâyetle dediler
$k i$ bundan evvel her ne cins post gelirse esnafimıdan gayr kimse 
almazdl. Beş altı yıl vardır ki pazarcı gibi, attar gibi başka esnaf da alır oldular..." (KİB 1998, 20).

Yeterli hammaddenin olmamasının yanı sıra hammaddenin fiyatındaki artış da narhın bozulmasında bir başka etkendir:

“...Fakat sekizyüz doksan beş yılından beri bugüne kadar her yılda batmanı dört beş akça ziyadeye çıkarak bugün ham yağın batmanı elli akça olmuş. Ve mumun okkası beş akça, çırak yă̆l dört buçuğa, ciğer yă̆l dört akça ve işkembe yağı üç buçuğa olup tümü değişmiş. Bundan böyle eski narhinin uygulanmast istenince, mumcular ve sabuncular biz eski narh üzere satamayız. Çünkü kasaplar yağı evvelkinden pahalıya satarlar..." (KİB 1998, 27).

Narh sisteminin denetimi sonrası tespit edilen bozulma kanunname ile tekrar düzenlenmektedir. $\mathrm{Bu}$ yeni düzenlemede fiyatların belirlenmesinde dikkat edilen hususların başında ürünün özelliği gelmektedir. Narh konulacak ürünün dayanıklılı̆̆1, mevsimsel özellikleri, kullanılan hammaddenin kalitesi ve işçiliği göz önüne alınır. Bunun yanı sıra ürünü satan esnafın vasfi da göz önüne alınır. Başka bir ifade ile seyyar satılan ürün ile dükkânda satılan ürün için ayrı hesaplamalar yapılmaktadır. Bununla birlikte narh sisteminde dikkate alınan bir başka husus ise İstanbul'da geçerli olan narhlardır. İstanbul narhları Bursa' daki bazı işkollarında uygulanmaktadır.

\section{Sonuç}

1502 tarihli kanunnameye göre Bursa'da dört beş yıl öncesine kadar işlerliğe sahip bir narh sistemi bulunduğu anlaşılmaktadır. Esnaf tarafından açık bir şekilde ifade edilen bu narh sisteminin bozulmasında ağırlıklı olarak kamu görevlilerinin ihmalleri, rüşvet almaları ya da bozuk sisteme göz yummaları rol oynamıştır. Ancak görevini yerine getirmeyen ya da ihmal eden görevliler için herhangi bir cezanın uygulanıp uygulanmadığına kanunname metninde rastlanmamıştır.

Bunun yanı sıra denetimler sırasında ortaya çıkan ve daha önceden hiçbir narh önerilmeyen ayakkabıcı ve sarraç gibi bazı iş kollarına da narh konulması yoluna gidilmiştir. Burada bir de narh koymanın mümkün görülmediği durumlarla da karşılaşılmıştır. Şöyle ki; kökelçi esnafında da eskiden kanun bulunmamasına rağmen bezlerin enlerinde karışıklık bulunduğu için narh koymak mümkün olmamıştır.

Narhın belirlenmesinde öncelik insanların temel ihtiyaçlarına verilmiştir. Ekmek bu ihtiyaç maddelerinin başında gelmektedir. Bu yüzden ekmeğin yapıldığı unun özellikleri ve ekmeğin pişirilme şekli ile piştikten sonraki durumu üzerine standartlar konulmuştur. Bu standartlar her ne kadar üretici için belirlenmiş olsa da bir noktada tüketicinin haklarını ve sağlı̆̆ını koruması bakımından önemlidir. Narh sisteminin tüketici haklarını korumaya yönelik bir eylem olduğunun başka bir göstergesi de narhın belirlenme şeklidir. Esnafın yanı sıra halkın yani tüketicinin de görüşleri ve fikirleri alınarak narhın oluşturulması hayata geçirilen sistemin tek taraflı olmadığının da göstergesidir.

Narh sistemi aynı zamanda tüketici ve üretici haklarının yanı sıra lokal ekonomik yapıyı denetleme imkanı da vermektedir. Hangi ürünün üretildiği, üretime giren hammaddenin hangileri olduğu ve üretilen malın hangi fiyata satıldığ gibi bilgileri içeren bu sistem devletin önemli gelir kaynaklarından birisi olan verginin hesaplanmasında da temel göstergeler arasındadır. Bunun yanı sıra kanun, üretici ile tüketici arasındaki ilişkileri düzenleyerek üreticinin emeğinin karşıllı̆ını alabilmesi, tüketicinin de hiçbir ürünün eksikliğini hissetmeden, hilesiz şekilde 
ulaşabilmesi bakımından bir sosyal devlet uygulaması olarak kabul edilebilir.

1502 tarihli Bursa'ya ait İhtisab Kanunnamesi, Osmanlı'da üretim alanında bir standart vesikası olarak okunabilmesinin yanı sıra üretim ve tüketim ilişkilerini, üretim üzerindeki devlet denetimini, standartları belirlenmiş ürünler ile halk sağlığına ilişkin uygulamaları ortaya koyması açısından önemli bir kaynaktır.

\section{KAYNAKÇA}

Ahmed Bâdî Efendi (2014). Riyâz-ı Belde-i Edirne 20. Yüzyıla Kadar Osmanlı Edirnesi. Mayıs 2014.

Akgündüz A. \& Öztürk S.(1999). 700. Yllinda Bilinmeyen Osmanll. İstanbul 1999.

Akkuş M. (2009). “19. Yüzyılda Bursa'daki İpek Ticaretini Geliştirmeye Yönelik Bir Kurum: Vapur Kumpanyası ve Nizamnamesi". OTAM 24 (2009) 1-20.

Anhegger R. \& İnalc1k H. (1956). Kânûnnâme-i Sultânî Ber Mûceb-i Örf-i Osmânî, (II. Mehmed ve II.Bayezid Devirlerine Ait Yasaknâme ve Kanunnâmeler). Ankara 1956.

Ebû Abdullah Muhammed İbn Battûta Tancî (2000). İbn Battûta Seyahatnâmesi. İstanbul 2000.

Erdoğdu İ. (2001). "Osmanlı İktisadi Düzeninde İhtisab Müessesesi ve Muhtesiblik Üzerine Deneme". OTAM 11 (2001) 123-145.

Faroqhi S. (2006). Osmanlı Şehirleri ve Kırsal Hayatı. Ankara 2006.

İnalcık H. (1960). "Bursa, XV. Asır Sanayi ve Ticaret Tarihine Dair Vesikalar". Belleten XXIV/93 (1960) 45-102.

İnalc1k H. (1992). “Bursa”. Diyanet İslam Ansiklopedisi. Cilt 6 (1992) 445-449.

İnalcık H. (2000). Osmanl İmparatorluğu'nun Ekonomik ve Sosyal Tarihi (1300-1600). İstanbul 2000.

Kanunname-i İhtisab-ı Bursa (1998). Ankara 1998.

Karataş Ş. (2012). “Osmanlı'da Tüketici ve Hayvan Hakları Tüzüğü”. İstanbul Aydın Üniversitesi Dergisi $4 / 13(2012) 47-52$.

Kazıcı Z. (1985). "Osmanlılar Döneminde İhtisab Teşkilatının Köle Haklarını Koruması". Beşinci Milletler Arası Türkoloji Kongresi Tebliğler (1985) 332-333. İstanbul.

Kazıc1 Z. (1998). "Hisbe". Diyanet İslam Ansiklopedisi. Cilt 18 (1998) 143- 145.

Kur'an-l Kerim, Al-i İmran, 3/104; Tevbe, 9/71, 112; Hud 11/116.

Kütükoğlu M.S. (2006). "Narh”. Diyanet İslam Ansiklopedisi. Cilt 32 (2006) 390-391.

Maydaer S. (2006). "Osmanlı Klasik Döneminde Kadınların Servet Edinme Yolları (Bursa Örneği)". Uludağ Üniversitesi İlahiyat Fakültesi Dergisi 15/2 (2006) 365-381.

Mehmed Süreyya (1996). "Muhyiddin Efendi (Yaralıca)". Sicill-i Osmani 4 (1996).

Öneş E. R. (1985). Osmanlı İmparatorluğu'nda Devlet ve Esnaf. İstanbul 1985.

Öz M. (2007). "Reâyâ". Diyanet İslam Ansiklopedisi. Cilt 34 (2007) 490-493.

Schiltberger J. (1997). Türkler ve Tatarlar Arasinda (1394-1427). İstanbul 1997.

Tabakoğlu A. (1989). “İslâm Fiyatlama İlkelerinin Osmanlı Dönemindeki Uygulaması”. Beşinci Milletler Arası Türkoloji Kongresi Tebliğler 2 (1989) 620-625.

Tabakoğlu A. (2005). Íktisat Tarihi. İstanbul 2005.

Turan Ş. (1992). "Bayezid II”. Diyanet İslam Ansiklopedisi 5 (1992) 234-238.

Yıldız M. (2010). "Osmanlı'da Ürünlerin Dini/ Şer'i Standardizasyonunda Dönüm Noktası: Tâhirdir Damgalı Sertifikasyona Geçiş”. Turkish Studies 5/1 (2010) 1468-1493. 